\title{
Comparison of Reward Management Practices: Reference to the Epigraph of King Mahinda IV (1026-1042 AC) and Armstrong's Reward Management Model
}

\section{K. D. Padmasiri ${ }^{1}$, R. Sirisumangala ${ }^{2}$, M. D.R Harshani ${ }^{3}$}

\section{Abstract}

Reward management is a significant function in Human Resource Management since its success generates lot of progressive consequences to the organization and to employees. To date, research endeavors on reward management are confined to investigate existing practices and yet to be analyzed historical applications. In order to execute mysterious in the present business context it is required to explore ancient reward management practices which were successfully implemented during the ancient era in managing rewards of employees. Accordingly, this study strives to find reward management practices applied in human resources management of monasteries during 1026 -1042 AC in Sri Lanka. Further, the research objectives of this study are to find the defined way of reward management during 1026-1042 AC, to find ancient reward management practices, and to compare reward management practices then and now. The present study applied a qualitative approach, in particular a content analysis method. Data was collected through secondary sources and the main source was the Epigraph of King Mahinda IV (1026-1042 AC) which is located in Mihintale, Sri Lanka. Analysis indicates that there were effective reward management practices in ancient times. The comparison of contemporary reward management and ancient reward management practices highlighted the variances and similarities in managing rewards of employees of two contexts; monasteries and organization.

Keywords: Ancient, Epigraph, Monastery, Reward Management
${ }^{1}$ Department of Human Resource Management, University of Kelaniya, Sri Lanka.

dinithipadmasiri@kln.ac.lk

${ }^{2}$ Department of Social Sciences and Comparative Studies, Bhiksu University of Sri Lanka.

sirisumangala80@gmail.co $\mathrm{m}$

${ }^{3}$ Department of Human Resource Management, University of Kelaniya, Sri Lanka.

rasikah@kln.ac.lk

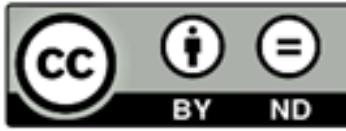

This article is published under the Creative Commons CC-BY-ND License (https://creativecommons.org/licenses/by-nd/4.0/). This license permits use, distribution and reproduction, commercial and non-commercia, provided that the original work is properly cited and is not change anyway. 


\section{Original Article}

\section{INTRODUCTION}

In line with the definition declared by Armstrong and Taylor (2014), Human Resource Management (HRM) can be defined including functions; people resourcing, learning and development, performance management, reward management, employee relations, and employee wellbeing. In particular, reward management is recognized as one of the prominent HRM functions. Admits to that Armstrong (2009) defined reward management is concerned with the formulation and implementation of strategies and policies in order to reward people fairly, equitably and consistently in accordance with their value to the organization. In addition, reward management consists of strategies, policies, and processes, and leads to ensure the value of people and ultimately, supports to achieve organizational, departmental and team goals.

In a religious perspective, the pioneer of HRM concept was the Lord Buddha in 600 B.C (Padmasiri, 2016). Though, reward management has been investigated in previous studies (E.g., Azasu, 2012), there is yet to be explored about reward management practices in ancient Sri Lankan. Thereby, the current study aims to explore ancient reward management practices in Sri Lanka. However, the major focus of this study was on the Epigraph of King Mahinda IV (10261042 AC). Karunarathne (2014), Wimalakiththi(1969) and Amarawansa
(2014) have conducted various studies by referring to this selected epigraph. However, they were not compared ancient reward management practices with present scenario but have done a deep investigation about the information in the epigraph.

According to 'Brahmi Transcripts', it's obvious that after the Arahant Mahinda Thera's promulgation of Buddhism, Buddhism was spread out all around Sri Lanka. At that time, Buddhism was the capital religion in Sri Lanka. As a result, the government helped to spread and develop Buddhism and temples across the country. While Kings, princes, people and rich people offered their lands, paddy fields, water tanks to those temples. Buddhist temples thus become more powerful institutes. Temples, therefore, required to have a sufficient number of staff members and workers to maintain those assets (Amarawansa, 2014).

\section{STATEMENT OF THE PROBLEM}

Buddhist doctrines state that Buddhist monks should not be accepted servants (DIGHA NIKAYA, I), though it became necessary as resources and infrastructure of temples were increased. Thereby, workers/ servants initiated and continued their works. According to Mihintala Pillar Inscriptions, there were over 200 workers for various types of works in that temple (Amarawansa, 2014). 


\section{Original Article}

Nevertheless, to date, it is yet to be explored ancient HRM practices in Sri Lanka by referencing Mihintala Pillar Inscriptions or by referencing any ancient sources in business management literature. So far, the existing literature does not support to understand differences or similarities between ancient and present HRM practices. Yet scholars are not communicated such insights to the present business world since management and archaeology disciplines are not associated each other through research endeavors in the Sri Lankan context. However, it is not clear how ancient reward management practices can be adopted in the present business context. This paper thus answers following questions: how reward management was defined during 1026-1042 AC?, what reward management practices were applied in managing $H R$ of monasteries during 1026-1042 AC? and what are the similarities and differences of reward management practices during $1026-1042$ $A C$ and today?

\section{PURPOSE AND OBJECTIVES OF THE STUDY}

The purpose of the study is to find reward management practices applied in managing $\mathrm{HR}$ of monasteries during 1026 -1042 AC. Based on the central purpose, specific objectives are derived to find how reward management was defined during 1026-1042 AC, to find ancient reward management practices during 1026 -
$1042 \mathrm{AC}$, and to compare today's reward management practices with ancient reward management practices by referencing the Epigraph of King Mahinda IV (1026-1042 AC) and Armstrong's (2012) reward management model.

\section{LITERATURE REVIEW}

\section{Reward Management}

The present study follows the model presented by Armstrong (2012) to describe the systematic reward management process, which is a wellknown model in the current business environment. The following discussion is about the model depicts in Figure 1.

The initial step of the reward management model is establishing a business strategy. It implies that business strategies are drivers of any organization. Those strategies drive to establish reward strategy and policy. Strategy can be defined as longer-term intention regarding the pay structures, merit pay, contingent pay, employee benefits, and total reward approach. Business strategy should associate with the reward strategy and policy or it can be further stated as business strategy and reward strategy collectively contribute to achieve organization mission. Reward strategy and policy can be influenced by context and reward philosophy. Reward philosophy consists of the set of values and beliefs and it could be in implicit form as some organizations apply different approaches in managing reward system but they do 


\section{Original Article}

not publish it or document it. However, reward philosophy is about the ways employees are paid, the level of payment, the extent to which payment should be related to performance, etc (Azasu, 2012). Context defines where the organization operates and it can be further elaborated as internal and external. In internal context organization culture, structure, operations, and size can be described while in the external context economic and competitive environment present.

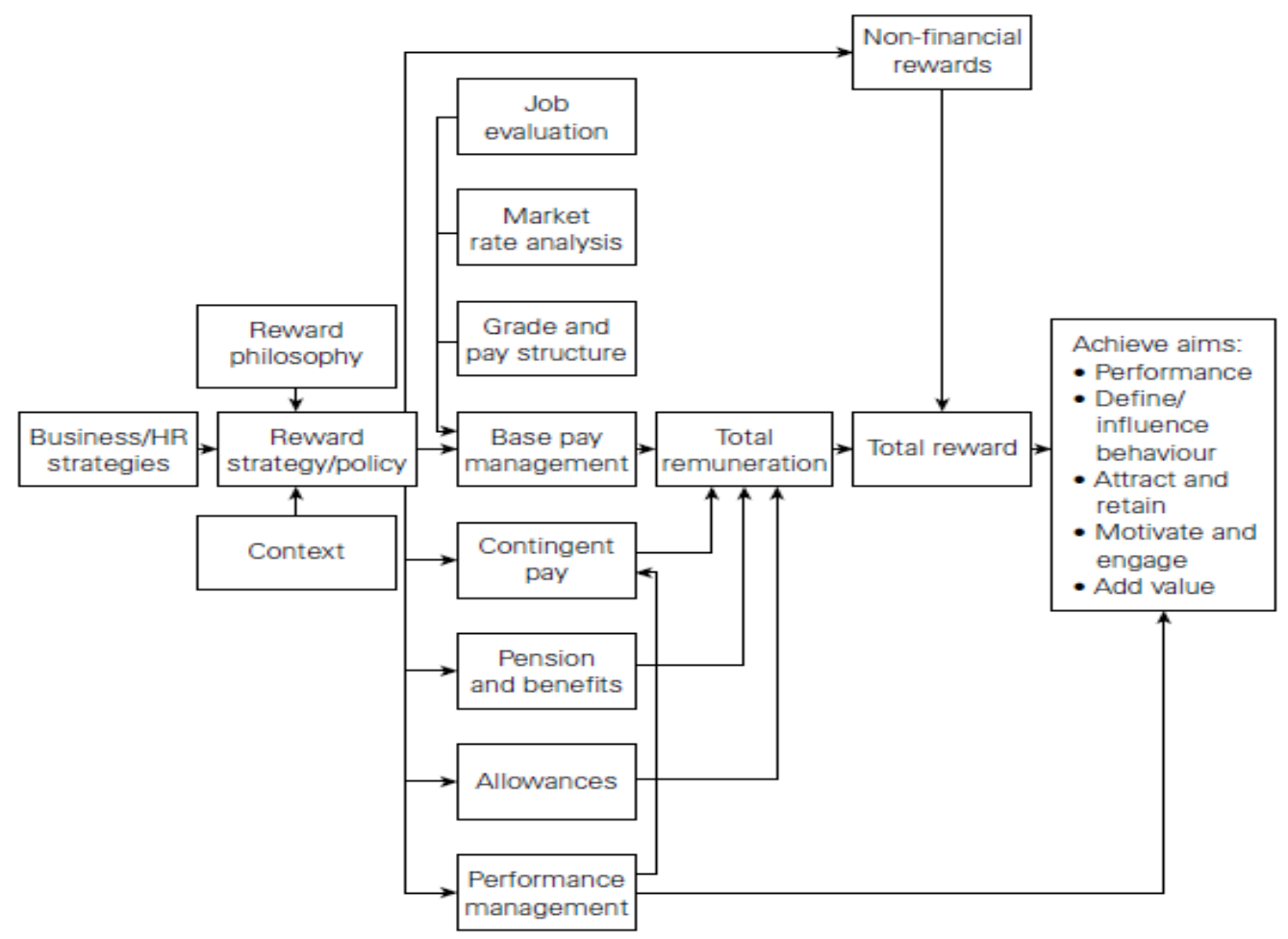

Figure 1: Reward Management Model Source,(Armstrong, 2012)

Further, this model has explained organizational culture consists of shared values, norms and assumptions. So, this organizational culture impacts the reward strategy and policy of the organization. According to the model, another key point in internal context is organization type, which affects reward strategy and policy of the organization. An organization can be bureaucratic or post-bureaucratic (Trevor, 2012 as cited in Armstrong,
2012). Furthermore, Armstrong (2012) defined bureaucratic and postbureaucratic as follows: Bureau critic organizations apply multi-graded pay structure; performance-based pay, fixed range of benefits, and centralized control of pay decisions. Nevertheless, post-bureaucratic organizations apply spot rates, skills and competent ices based pay system, and flexible benefits. In the external context globalization, rates of pay in the market, the economy and societal 


\section{Original Article}

factors, legislations, and trade unions can be explained (Armstrong, 2012). These factors are influenced to reward policy of the organization hence, based on these external environmental factors organizations' practices are changing. For example, in international HRM, could be seen expatriates accordingly, to manage their rewards organization should adapt to the global needs.

According to Armstrong (2012), base pay management is decided by theses external factors; globalization, rates of pays in the market, the economy and societal factors, legislations, and trade unions. Furthermore, he simplified base pay as the foundation rate for the job and this belief as one of the components when deciding total remuneration and contingency pay is another component of total remuneration which related to performance, competence, contribution, skill or length of service of an employee. It was processed by adding the contingency pay amount to the base pay and it is subjective in nature since this adjusts with individual performance, competency and contribution (Armstrong, 2012). In addition, he stated that the performance management system of the organization is supporting the contingency pay and it provides inputs and it decides the contingency pay.

The performance management process is an evaluation of individual performance, provide regular constructive feedback, and result in agreed plans for performance improvement, and learning and personal development (Armstrong, 2012). The employee's total remuneration includes pension and benefits such as sick pay, an insurance cover and also identified as another payment which is added to employee's total remuneration (Azasu, 2012). Moreover, the same paper mentioned that the location allowances, overtime payments, shift payments, telephone allowances, and transport allowances are paid in addition to basic pay in special circumstances.

Total remuneration consists with all financial benefits and total rewards include financial base pay, contingent pay, pension and benefits, and allowances and non-financial benefits (Azasu, 2012). However, the nonfinancial rewards such as recognition, achievement, autonomy, scope to use and develop skills, training and career development opportunities do not involve any direct payments and often arise from the work itself (Azasu, 2012). According to Azasu (2012), rewards are social exchanges; they could be drivers of employee engagement within the firms. The aggregate of financial and nonfinancial rewards that any employer offers are thus meant to attract, retain and elicit reciprocal performance of its employees. Correspondingly reward management is concerned with the strategies, policies and processes 


\section{Original Article}

required to ensure that the value of people and the contribution they make to achieving organizational departmental and team goals are recognized and rewarded Armstrong (2010).

\section{METHODOLOGY}

The present study applied a content analysis method to investigate on the above-mentioned research problem (Erlingsson \& Brysiewicz, 2017)and focus was on the Epigraph of King Mahinda IV (1026-1042 AC). According to Erlingssonand Brysiewicz (2017) content analysis is a method for summarizing any form of content by counting various aspects of the content and further they stated that identifying and condensing meaning units, coding, and categorizing are not one-time events but it is a continuous process. Thereby, researchers of the present study conducted content analysis in analyzing raw data received from the Epigraph and compared data with the selected Reward Management Model of Armstrong (2012).Researchers selected the epigraph of King Mahinda IV (1026-1042 AC) as the main source of data since it broadly describes ancient reward management practices (Amarawansa, 2014). This epigraph is located in Mihintale (situated $12 \mathrm{~km}$ away from Anuradhapura, Sri Lanka) and there are two inscriptions which have 18 lines in each. Size of the inscription is High - 7 feet, and Width 4 feet and size of letter is $7 / 8$.

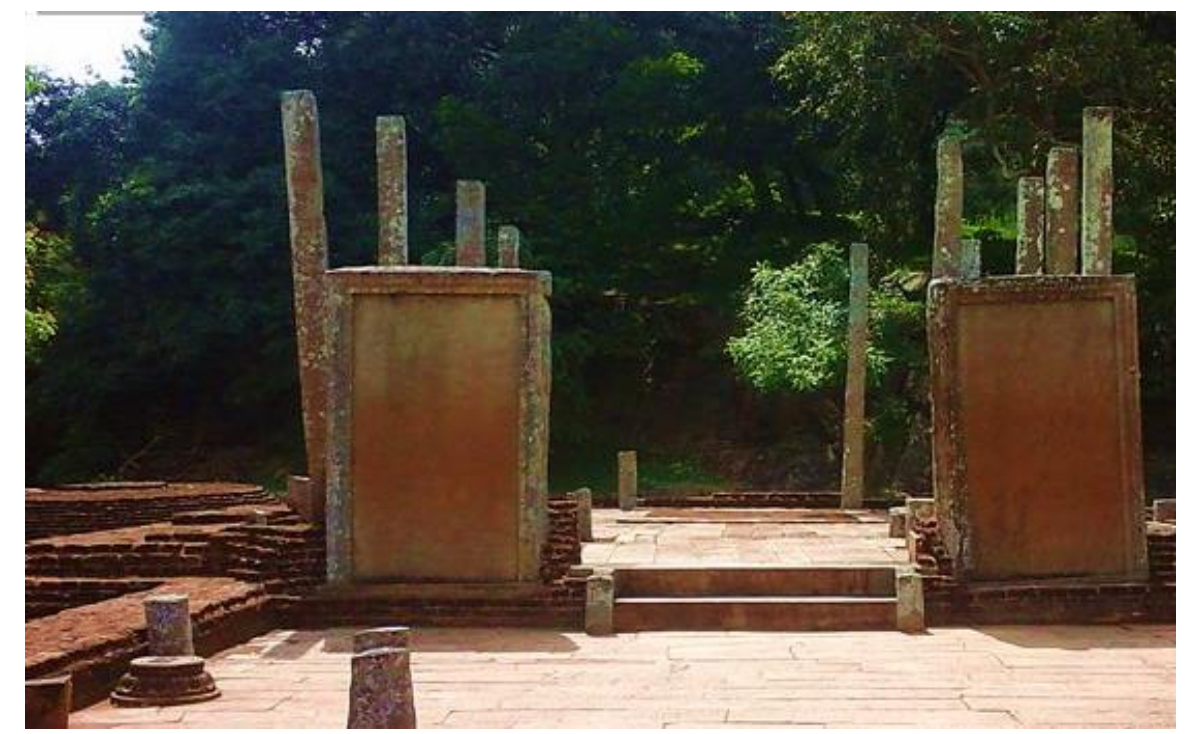

Figure 2: Two Slab Inscriptions of Mahinda IV

\section{FINDINGS}

As asserted in the previous discussions, there were (02) two inscriptions in the selected epigraph and information available in those inscriptions are elaborated in the following paragraphs. 


\section{Original Article}

Inscription 01: The inscription describes the interval administration of 'cetiyagiri monastery' (one of the monasteries). Furthermore, monk disclosures the disciplinary rules which must be followed by dwelling monks of the monastery as well as it gives accounts on king's codification patronage forwards the monks.

Inscription 02: The epigraphy discloses the income of the monastery and it reveals wages that were given to the workers daily and monthly.

The present study investigates information on the second epigraph in which the rewards given to the workers for their service were described. According to Rahula (2006), even though workers or servants are given and dedicated to temples by Kings, Buddhist monks are not allowed to accept them. However due to the difficulty of managing resources under their control, Buddhist monks accepted workers as coordinators in their temples. This epigraph mentioned that workers gained considerable salary for that. Findings show that wages were given as 'Divel, Kiriya, Pala, Pada, Aka and Kalan' (measurement scales) (see Table1-3).

In line with the content analysis process suggested by Erlingsson and Brysiewicz (2017), information on
Epigraph of King Mahinda IV (10261042 AC) was categorized into three major topics as per the levels of jobs; top/ strategic, managerial and operational. These three levels were identified from the study conducted by Burgelman (1983). According to him, Top management is a critical contribution that consists of strategic recognition rather than planning and makes sure that entrepreneurial activities are corresponded to their strategic vision, retroactively. Further he indicated that Middle-level managers are the individuals who play a crucial role and in this though they support for autonomous strategic initiatives by conceptualizing strategies for new areas of business.

Finally, new managerial approaches and innovative administrative arrangements are required to facilitate the collaboration between entrepreneurial participants and the organizations in which they are active. It is facilitated by the operational level management of an organization (Burgelman, 1983).

Accordingly, jobs described in the Epigraph of King Mahinda IV (10261042 AC) were categorized into three levels: top/ strategic, managerial and operational and the summary was presented in Tables 1-3. 


\section{Original Article}

Table 1: Reward Management in Monasteries: Top/ Strategic Level

\begin{tabular}{|c|c|c|c|c|}
\hline Designation/Job & Task/Responsibility & Material & Money & Land \\
\hline $\begin{array}{l}\text { The speakers of } \\
\text { the Tripitaka }\end{array}$ & $\begin{array}{l}\text { The speakers of the } \\
\text { Tripitaka and taking } \\
\text { care of } \\
\text { Abhayagiriya } \\
\text { monastery }\end{array}$ & $\begin{array}{l}\text { 'Wasag 5' } \\
\text { 'Wasag 12' } \\
\text { Daily - 'HaalNali 1' }\end{array}$ & $\begin{array}{l}\text { 'Rankaln } \\
\text { 1(Was } \\
\text { WasanaPawa } \\
\text { rana) Akha 4' }\end{array}$ & \\
\hline The treasurer & The treasurer & & & 'Kiri 5' \\
\hline $\begin{array}{l}\text { Defense of the } \\
\text { monasteries }\end{array}$ & $\begin{array}{l}\text { Defending the } \\
\text { monasteries }\end{array}$ & 'Haal' & & 'Kiriya 1' \\
\hline $\begin{array}{l}\text { The organizer of } \\
\text { the Functions }\end{array}$ & $\begin{array}{l}\text { Organizing the } \\
\text { functions }\end{array}$ & 'DamiyenWasag 1' & $\begin{array}{l}\text { 'Rankaln 1' } \\
\text { 'Akha 2' }\end{array}$ & 'Kiriya 1' \\
\hline $\begin{array}{l}\text { The } \\
\text { Superintended } \\
\text { of the } \\
\text { Meditation cave }\end{array}$ & $\begin{array}{l}\text { The superintending } \\
\text { of the Meditation } \\
\text { caves }\end{array}$ & 'DamiyenWasag 1' & 'Ran kalan 1' & 'Paya 2' \\
\hline $\begin{array}{l}\text { The } \\
\text { administrative } \\
\text { of the water } \\
\text { board }\end{array}$ & $\begin{array}{l}\text { Administrating of } \\
\text { the water board }\end{array}$ & $\begin{array}{l}\text { 'HaalAdhaMaana } \\
\text { 1'Patha 1' }\end{array}$ & & \\
\hline $\begin{array}{l}\text { The executive } \\
\text { duties }\end{array}$ & The executive duties & 'HaalNali 1' & $\begin{array}{l}\text { 'En Kalan } \\
15^{\prime}- \\
\text { Annually }\end{array}$ & $\begin{array}{l}\text { 'Kiri 5' - } \\
\text { Life time }\end{array}$ \\
\hline $\begin{array}{l}\text { The domestic } \\
\text { controller }\end{array}$ & $\begin{array}{l}\text { Controlling the } \\
\text { domestic }\end{array}$ & 'HaalAdhaMaana 2' & & $\begin{array}{l}\text { 'Kiri 1' } \\
\text { 'Paya 2' }\end{array}$ \\
\hline $\begin{array}{l}\text { Administrative } \\
\text { of the stone } \\
\text { work }\end{array}$ & $\begin{array}{l}\text { Administrating and } \\
\text { making the stone } \\
\text { works }\end{array}$ & & & \\
\hline $\begin{array}{l}\text { The controller of } \\
\text { the Alms hall } \\
\text { maid }\end{array}$ & $\begin{array}{l}\text { Controlling the } \\
\text { Alms hall maid }\end{array}$ & $\begin{array}{l}\text { 'Adhamana 1' } \\
\text { 'Patha 2' }\end{array}$ & & 'Paya 1' \\
\hline $\begin{array}{l}\text { Protector for the } \\
\text { palace of temple } \\
\text { tooth }\end{array}$ & $\begin{array}{l}\text { Protecting the the } \\
\text { palace of temple } \\
\text { tooth }\end{array}$ & 'HaalNali 1' & & \\
\hline $\begin{array}{l}\text { The Abigail } \\
\text { Controller }\end{array}$ & $\begin{array}{l}\text { Controlling the } \\
\text { Abigail }\end{array}$ & & $\begin{array}{l}\text { 'Ran Kalan } \\
\text { 1( For the } \\
\text { Uniforms)' - } \\
\text { Annually }\end{array}$ & 'Paya 1' \\
\hline $\begin{array}{l}\text { Message } \\
\text { Administrator }\end{array}$ & $\begin{array}{l}\text { Administrating the } \\
\text { messages }\end{array}$ & 'HaalAdhaMaana 1' & & 'Kiriya' \\
\hline
\end{tabular}




\section{Original Article}

\begin{tabular}{|l|l|l|l|l|}
\hline $\begin{array}{l}\text { The } \\
\text { administrative } \\
\text { of the palace } \\
\text { controlling }\end{array}$ & $\begin{array}{l}\text { The administrative } \\
\text { of the palace } \\
\text { controlling }\end{array}$ & $\begin{array}{l}\text { 'HaalAdhaMaana 1' } \\
\text { 'Patha 1' }\end{array}$ & & 'Paya 1' \\
\hline Doctor & & & $\begin{array}{l}\text { 'Dethisasene } \\
n \text { Niya } \\
\text { Paliyk' }\end{array}$ \\
\hline $\begin{array}{l}\text { Doctor for } \\
\text { treatment for the } \\
\text { leach }\end{array}$ & $\begin{array}{l}\text { The treatments for } \\
\text { the leach }\end{array}$ & 'DemiyenWasag 1' & & 'Paya 1' \\
\hline
\end{tabular}

Table 2: Reward Management in Monasteries: Managerial Level

\begin{tabular}{|c|c|c|c|c|}
\hline $\begin{array}{c}\text { Designation/Jo } \\
\text { b }\end{array}$ & Task/Responsibility & Material & Money & Land \\
\hline Creator & $\begin{array}{l}\text { Crating the } \\
\text { decorations }\end{array}$ & $\begin{array}{l}\text { 'HaalAdhaMaan } \\
a \text { 2' }\end{array}$ & & 'Paya 2' \\
\hline $\begin{array}{l}\text { The organizer } \\
\text { of the } \\
\text { drummers }\end{array}$ & $\begin{array}{l}\text { Organizing the } \\
\text { Drummers }\end{array}$ & $\begin{array}{l}\text { 'HaalAdhaMaan } \\
\text { a 1' } \\
\text { 'Patha 2' }\end{array}$ & & 'Paya 2' \\
\hline $\begin{array}{l}\text { The water } \\
\text { board }\end{array}$ & The water board & $\begin{array}{l}\text { 'DamiyenWasag } \\
1 \text { ' }\end{array}$ & & $\begin{array}{l}\text { 'Paa 2' - Life } \\
\text { Time }\end{array}$ \\
\hline $\begin{array}{l}\text { Fellow worker } \\
\text { controller }\end{array}$ & $\begin{array}{l}\text { Controlling the } \\
\text { fellow workers }\end{array}$ & $\begin{array}{l}\text { 'HaalAdhaMaan } \\
\text { a 1'Patha 1' }\end{array}$ & & \\
\hline Preaching & Preaching & & & 'Guuthagama' \\
\hline $\begin{array}{l}\text { Stage } \\
\text { controller }\end{array}$ & Stage controlling & $\begin{array}{l}\text { 'DemiyenWasag } \\
1 \text { ' }\end{array}$ & & 'Paya 1' \\
\hline Astrology & $\begin{array}{l}\text { The duties of the } \\
\text { astrology or the } \\
\text { astrological duties }\end{array}$ & $\begin{array}{l}\text { 'DemiyenWasag } \\
1 \text { ' }\end{array}$ & & 'Paya 1' \\
\hline $\begin{array}{l}\text { The three types } \\
\text { of Stupa }\end{array}$ & $\begin{array}{l}\text { Cleaning, } \\
\text { supervision and } \\
\text { reformation of the } \\
\text { three types of Stupa }\end{array}$ & $\begin{array}{l}\text { 'HaalAdhamana } \\
\text { 1' }\end{array}$ & & 'Paa 2' \\
\hline
\end{tabular}

Table 3: Reward Management in Monasteries: Operational Level

\begin{tabular}{|l|l|l|l|l|}
\hline $\begin{array}{c}\text { Designation/J } \\
\text { ob }\end{array}$ & Task/Responsibility & \multicolumn{1}{|c|}{ Material } & Money & Land \\
\hline $\begin{array}{l}\text { The lamps } \\
\text { supplier }\end{array}$ & Supplying the lamps & $\begin{array}{l}\text { 'DamiyenWasag } \\
1^{\prime}\end{array}$ & 'Rankaln 1' & 'Kiriya 1' \\
\hline The messenger & Taking the messages & 'Adhamana 2' & & 'Paa 2' \\
\hline Maid & Maid & 'Adhamana 1' & & \\
\hline
\end{tabular}




\section{Original Article}

ISSN: 2279-3933

\begin{tabular}{|c|c|c|c|c|}
\hline $\begin{array}{l}\text { Belongs to } \\
\text { Abhayagiriya } \\
\text { Monastery } \\
\end{array}$ & $\begin{array}{l}\text { Belongs to } \\
\text { Abhayagiriya } \\
\text { Monastery } \\
\end{array}$ & $\begin{array}{l}\text { 'DamiyenWasag } \\
1 \text { ' }\end{array}$ & & 'Paya 2' \\
\hline $\begin{array}{l}\text { The bowl } \\
\text { supplier }\end{array}$ & Supplying the bowls & 'HaalPatha 2' & & 'Paya 1' \\
\hline $\begin{array}{l}\text { Two securities } \\
\text { to protect } \\
\text { Cheewara, } \\
\text { Pindapatha, } \\
\text { Senasana, and } \\
\text { Gilanaprathya } \\
\text { ya }\end{array}$ & $\begin{array}{l}\text { Protect Cheewara, } \\
\text { Pindapatha, } \\
\text { Senasana, and } \\
\text { Gilanaprathyaya }\end{array}$ & 'Adhamana 1' & & \\
\hline $\begin{array}{l}\text { The Store } \\
\text { Keeper }\end{array}$ & Store Keeping & $\begin{array}{l}\text { 'HaalAdhaMaan } \\
a 1^{\prime}\end{array}$ & & 'Paya 1' \\
\hline Rice Cooker & $\begin{array}{l}\text { Providing the woods } \\
\text { and cooking rice }\end{array}$ & $\begin{array}{l}\text { 'HaalAdhaMaan } \\
\text { a 3' }\end{array}$ & & \\
\hline Checker & Checking & 'Patha 2' & & \\
\hline Grinder & Grinding & & $\begin{array}{l}\text { 'Ran Kalan 1( } \\
\text { For the } \\
\text { Uniforms)' - } \\
\text { Annually }\end{array}$ & 'Paya 1' \\
\hline $\begin{array}{l}\text { Wood } \\
\text { provider }\end{array}$ & Providing the Woods & 'Haal' & & \\
\hline Cooker & Cooking & & & $\begin{array}{c}\text { 'Tharalala } \\
\text { Gamin Kiriya } \\
01 '\end{array}$ \\
\hline $\begin{array}{l}\text { Cloth provider } \\
\text { as filters }\end{array}$ & $\begin{array}{l}\text { Providing the clothes } \\
\text { made as Filters }\end{array}$ & & & 'Kiriya 1' \\
\hline The messenger & Taking the messages & 'Adhamana 2' & & \\
\hline Cooking Rice & $\begin{array}{l}\text { Cooking rice after } \\
\text { providing the woods }\end{array}$ & $\begin{array}{l}\text { 'HaalAdhaMaan } \\
a 1^{\prime}\end{array}$ & & \\
\hline Pottery maker & Pottery making & & & 'Kiriya 1' \\
\hline $\begin{array}{l}\text { The Colour } \\
\text { provider for } \\
\text { the robes }\end{array}$ & $\begin{array}{l}\text { The colour (Maroon) } \\
\text { providing for the } \\
\text { robes }\end{array}$ & $\begin{array}{l}\text { 'HaalAdhaMaan } \\
a \text { 2' }\end{array}$ & & 'Kiriya 1' \\
\hline $\begin{array}{l}\text { Flowers } \\
\text { Provider for } \\
\text { the main } \\
\text { image house }\end{array}$ & $\begin{array}{l}\text { Providing of flowers } \\
\text { for the main image } \\
\text { house }\end{array}$ & 'Wag 1' & & $\begin{array}{l}\text { 'Guuthagama } \\
\text { Paya 2' }\end{array}$ \\
\hline $\begin{array}{l}\text { Flowers and } \\
\text { sandal sticks } \\
\text { supplier }\end{array}$ & $\begin{array}{l}\text { Supplying flowers } \\
\text { and Sandal Sticks }\end{array}$ & $\begin{array}{l}\text { 'DemiyenWasag } \\
\text { 2' }\end{array}$ & & \\
\hline $\begin{array}{l}\text { The image } \\
\text { anointer }\end{array}$ & The image anointing & 'Patha 2' & & \\
\hline
\end{tabular}




\section{Original Article}

ISSN: 2279-3933

\begin{tabular}{|c|c|c|c|}
\hline Barber & Barber Duties & $\begin{array}{l}\text { 'DemiyenWasag } \\
1 \text { ' }\end{array}$ & 'Kiriya 1' \\
\hline $\begin{array}{l}\text { Water lily } \\
\text { supplier }\end{array}$ & $\begin{array}{l}\text { Supplying of water } \\
\text { lilies }\end{array}$ & & $\begin{array}{l}\text { 'Sapugamiyen } \\
\text { Kiri 2' }\end{array}$ \\
\hline $\begin{array}{l}\text { The security } \\
\text { officer in } \\
\text { Charge }\end{array}$ & $\begin{array}{l}\text { Controlling the } \\
\text { security officers }\end{array}$ & & $\begin{array}{l}\text { 'Karendaagam } \\
a^{\prime} \\
\text { - Life Time }\end{array}$ \\
\hline $\begin{array}{l}\text { Flowers and } \\
\text { Sandal } \\
\text { Provider }\end{array}$ & $\begin{array}{l}\text { Providing flowers } \\
\text { and Sandal }\end{array}$ & $\begin{array}{l}\text { 'DemiyenWasag } \\
4 \text { ' }\end{array}$ & \\
\hline $\begin{array}{l}\text { Flower } \\
\text { Supplier }\end{array}$ & Supplying flowers & $\begin{array}{l}\text { 'DemiyenWasag } \\
1 \text { ' }\end{array}$ & $\begin{array}{l}\text { 'Karendaagam } \\
\text { a Kiri 2' }\end{array}$ \\
\hline $\begin{array}{l}\text { The image } \\
\text { anointer }\end{array}$ & The image anointing & $\begin{array}{l}\text { 'HaalAdhamana } \\
\text { 2' }\end{array}$ & 'Paa 2' \\
\hline $\begin{array}{l}\text { Oil Provider } \\
\text { for the } \\
\text { anointing } \\
\text { Buddha Image } \\
\text { at the relic } \\
\text { house }\end{array}$ & $\begin{array}{l}\text { Providing oil for the } \\
\text { anointing Buddha } \\
\text { Image at the relic } \\
\text { house }\end{array}$ & $\begin{array}{l}\text { 'HaalAdhamana } \\
\text { 2' }\end{array}$ & 'Kiriya 1' \\
\hline $\begin{array}{l}\text { The rough } \\
\text { worker }\end{array}$ & $\begin{array}{l}\text { Doing the rough } \\
\text { work and carpenter } \\
\text { task }\end{array}$ & & 'Kiri 1' \\
\hline $\begin{array}{l}\text { The duties of } \\
\text { the craftsman }\end{array}$ & $\begin{array}{l}\text { The duties of the } \\
\text { main craftsman }\end{array}$ & & $\begin{array}{l}\text { ‘WaduDewag } \\
\text { ama' }\end{array}$ \\
\hline $\begin{array}{l}\text { Cart Rider, Re } \\
\text { builder and } \\
\text { Supervisor }\end{array}$ & $\begin{array}{l}\text { Cart Riding, Re } \\
\text { building and } \\
\text { supervising }\end{array}$ & & $\begin{array}{l}\text { 'DunugamaKi } \\
\text { riya 1' }\end{array}$ \\
\hline Iron objector & $\begin{array}{l}\text { Making the iron } \\
\text { objects }\end{array}$ & & 'Kiri 1' \\
\hline $\begin{array}{l}\text { White Wash } \\
\text { Burner }\end{array}$ & $\begin{array}{l}\text { Burning the White } \\
\text { wash }\end{array}$ & & $\begin{array}{l}\text { 'Hunu Bop } \\
\text { Dewagama' }\end{array}$ \\
\hline $\begin{array}{l}\text { Pure water } \\
\text { supplier }\end{array}$ & $\begin{array}{l}\text { Supplying the pure } \\
\text { water }\end{array}$ & & 'Sala 2' \\
\hline $\begin{array}{l}\text { The workers of } \\
\text { the relic house, } \\
\text { image house } \\
\text { and alms hall }\end{array}$ & $\begin{array}{l}\text { Working at the relic } \\
\text { house, image Houser } \\
\text { and alms hall }\end{array}$ & $\begin{array}{l}\text { 'DemiyenWasag } \\
\text { 2' }\end{array}$ & $\begin{array}{l}\text { 'Magulawena } \\
\text { Kiri 2' }\end{array}$ \\
\hline
\end{tabular}




\section{Original Article}

HaalNali= scale used to measure the weight of rice, Rankaln = type of money used during that time, Kiri, Kiriya, Paa, Paya, \& Sala =measurements scales used in measuring lands

* Spaces occurred since the information are not available in the Epigraph

Source: Amarawansa, (2014)

The present study followed the Reward Management model presented by Armstrong (2012) to conduct indepth analysis on reward management practices in ancient time. It is visible that ancient reward management practices are similar to the practices suggested in the Reward Management Model (Armstrong, 2012) which is shown in Figure 1. However, there are similarities and differences in reward management in these two eras (ancient and contemporary). The following Table4 illustrates a summary of the comparison of ancient and contemporary reward management practices. Furthermore, definition of each function and how those functions are practiced in ancient time has been elaborated in Table 4.

Table 4: Comparison of Ancient and Contemporary Reward ManagementPractices

\begin{tabular}{|c|c|c|}
\hline $\begin{array}{c}\text { Armstrong's } \\
\text { RM } \\
\text { functions } \\
\end{array}$ & Definition of Function & Ancient RM \\
\hline $\begin{array}{l}\text { Business } \\
\text { strategy }\end{array}$ & $\begin{array}{l}\text { The business drivers and sets out the } \\
\text { business goals }\end{array}$ & $\begin{array}{l}\text { The strategy was to } \\
\text { manage resources of } \\
\text { monasteries }\end{array}$ \\
\hline $\begin{array}{l}\text { Reward } \\
\text { philosophy }\end{array}$ & $\begin{array}{l}\text { The ways in which people are paid, the } \\
\text { levels of payment, the extent to which pay } \\
\text { should be related to performance, the scale } \\
\text { of employee benefits, degree to which } \\
\text { reward practices are ethical in the sense that } \\
\text { they are fair, equitable and transparent and } \\
\text { the adoption of total reward policies } \\
\text { which provide for both financial and non- } \\
\text { financial rewards }\end{array}$ & $\begin{array}{l}\text { There were differences in } \\
\text { employee salaries } \\
\text { according to their services }\end{array}$ \\
\hline Context & Situation & Monastery \\
\hline $\begin{array}{l}\text { Reward } \\
\text { strategy }\end{array}$ & Reward policy: how will pay for services & $\begin{array}{l}\text { Payments as per } \\
\text { employees' service }\end{array}$ \\
\hline $\begin{array}{l}\text { Non- } \\
\text { financial } \\
\text { rewards }\end{array}$ & $\begin{array}{l}\text { Recognition, achievement, autonomy, scope } \\
\text { to use and develop skills, training and career } \\
\text { development opportunities }\end{array}$ & Devoted job position \\
\hline $\begin{array}{l}\text { Job } \\
\text { evaluation }\end{array}$ & Evaluate jobs to decide basic pay & $\begin{array}{l}\text { Based on the worth of task } \\
\text { and paid differently }\end{array}$ \\
\hline
\end{tabular}




\section{Original Article}

\begin{tabular}{|l|l|l|}
\hline $\begin{array}{l}\text { Grade and } \\
\text { pay structure }\end{array}$ & Based on job position decide pay structure & $\begin{array}{l}\text { Clearly defined job } \\
\text { description and based on } \\
\text { that pay for services }\end{array}$ \\
\hline $\begin{array}{l}\text { Pension and } \\
\text { benefits }\end{array}$ & Reward after their service period & $\begin{array}{l}\text { Allow family member to } \\
\text { continue that same service } \\
\text { and gave land ownership }\end{array}$ \\
\hline $\begin{array}{l}\text { Contingent } \\
\text { pay }\end{array}$ & Payments which are related to performance & $\begin{array}{l}\text { Paid differently based on } \\
\text { level of tasks completed }\end{array}$ \\
\hline
\end{tabular}

Source: Authors

During 1026-1042 AC, reward management was defined as wages and allowances and the business strategy to manage the resources of monasteries (Rahula, 2006). Armstrong (2012) stated that the reward philosophy is the way in which people are paid, the levels of payment, the extent to which payment should relate to performance, the scale of employee benefits, degree to which reward practices are ethical in the sense that they are fair, equitable and transparent and the adoption of total reward policies which provide for both financial and non-financial rewards. However, there were differences in employee salaries according to their services, which can be identified as the reward philosophy in ancient times.

However, it is visible that in ancient period, reward management context was the monastery since there were over 200 workers for various types of works in that temple (Amarawansa, 2014). At present, the reward policy defines as how will pay for services (Armstrong, 2012) and in ancient times reward policy was 'pay as per employees' service. Similar to the present scenario, in ancient times jobs were evaluated based on worth of task and accordingly they are paid differently (Rahula, 2006). According to the epigraph, job responsibilities and duties are clearly defined and based on the tasks that the employees have to perform they could earn wages and allowances (Amarawansa, 2014). During that period employees were paid differently based on the tasks they completed and at present, we defined such pavements as contingency pay. In addition, in the ancient times, when employee is withdrawn from the duty any family member could continue the same service for monasteries, which implies the continuation of the service within the same family from generation to generation (Amarawansa, 2014). Furthermore, early land ownership was given for employees for their services other than giving only monetary rewards (E.g., see Tables 13).

\section{DISCUSSION}

The comparison of contemporary and ancient reward management practices acknowledges the pertinence of similarities in managing rewards of 


\section{Original Article}

ISSN: 2279-3933

employees. First, there was a reward strategy in the ancient period; pay for employees in accordance with their respective services. Second, even though jobs were not deeply evaluated during the ancient time, employees were paid differently based on the worth of the task. Third, clearly defined job descriptions were there and based on that paid for the services and it is similar to 'grade and pay structure' in contemporary reward management practices. Finally, it is found that employees were paid differently based on the level of task completed which is similar to the 'performance-based pay' today. Employees of monasteries were received land ownership (Divel) on behalf of their services. This is similar to 'pension and benefits' in today's reward management because employees and their family members can obtain benefits from such land ownerships after the service period.

Nevertheless, in the ancient times, the management of the monasteries allowed employee's family members to continue the same service when the employee ceased the service due to death or inability to perform further which is however quite different to the reality in the present scenario. In ancient times, their reward philosophy was pay for employees according to their contribution. In addition, it can be argued that even though reward management was defined as 'wages and allowances' they were not paid like allowances. According to
Armstrong (2012), allowances are paid addition to basic pay for special circumstances (E.g., telephone allowances) and as per the available information, this is not performed during the ancient period.

\section{CONCLUSION}

According to the fourth Mihinda's inscription, over 200 workers contributed their services to temples and there were systematic reward management practices during the period of 1026-1042 AC. This article has compared ancient and contemporary reward management practices using two main sources; Epigraph of King Mahinda IV (10261042 AC) and Armstrong's Reward Management Model (2012). The comparison of ancient and contemporary practices revealed that ancient practices are more similar to the cotemporary practices. However, researchers found that in spite of the similarities, those practices were defined differently in these two eras. Having an organization strategy, reward philosophy, reward strategy, context, non- financial rewards, job evaluation, market analysis, grade and pay structure, pension and benefits, and contingent pay are some of the similarities. Allowance is defined as the payment that the employee received in addition to basic salary (Armstrong, 2012). In ancient time, workers were not paid such additional payments other than wages but they defined reward management as wages and allowances. On the other hand, it 


\section{Original Article}

ISSN: 2279-3933

is identified a new method of payment; paying by lands for employees' contribution. This article thus highlights that ancient people managed employees' rewards successfully before it is recognized as a function in HRM by today's business world.

The present study encountered several limitations. First, a lack of literature on ancient reward management practices and depended only one Epigraph in collecting data. So, future researchers can investigate more sources to conduct an in-depth analysis of reward management practices. Second, the present paper explored one function of HRM: reward management, so that it prevented providing a detailed analysis of ancient HRM practices. Therefore, future scholars would conduct studies by covering all functions of HRM. Third, even though, there are various reward management processes mentioned in the literature, this paper considered only 'Armstrong's Reward System Model' as the basis for comparison.

\section{References}

Amarawansa Thero, K. (2014). LAKDIWA SEL LIPI. Maradana: S. Godage saha Sahodarayo. Sinahla.

Armstrong, M. (2012). Armstrong's Handbook of Reward Management Practice (4thEdition). United Kingdom: Koganpage.

Armstrong, M. (2010). Armstrong's Handbook of Reward Management Practice
(3rdEdition). United Kingdom: Koganpage.

Armstrong, M., \& Taylor, S. (2014). Armstrong's Handbook of Human Resource Management Practice. USA: Koganpage.

Atkinson, C., Lucas, R., Armstrong, M., Brown, D. and Reilly, P. (2011), "Increasing the effectiveness of reward management: an evidence-based approach", Employee Relations, Vol. 33 No. 2, pp. 106-120

Azasu, Z. (2012). Survey of reward management practices in the swedish real estate sector. Property Management, 30(5), 449-464

Burgelman, R. A. (1983). Corporate Entrepreneurship and Strategic Management: Insights from a Process Study. Management Science, 23(12), 1349-1455.

Digha Nikaya. In I Section (p. 49).

Erlingsson, C., \& Brysiewicz, P. (2017). A hands-on guide to doing content analysis. African Journal of Emergency Medicine, 7(3), 93-99.

Karunarathne, S. (2014). SHILA LEKHANA SANGRAHAYA. Colombo: Department of Archaeology.

Padmasiri, M. K. D. (2016). Buddhist perspective for organization human resource development: Reference to the maha mangala sutta. Universal Journal of Management, 4(7), 405-410.

Prouska, R., Psychogios, A. and Rexhepi, Y. (2016), "Rewarding employees in turbulent economies for improved organisational performance", Personnel Review, Vol. 45 No. 6, pp. $1259-1280$

Rahula Venrable Thero, W. (2006). LAKDIWA BHUDUSAMAYE ITHIHASAYA. 


\section{Original Article}

Maradana: S. Godage saha

Sahodarayo, Sinahla.

Smith, I. (1993), "Reward Management: A

Retrospective Assessment", Employee

Relations,

Vol. 15 No. 3, pp. 45-59
Wimalakiththi Venerable Thero, M. U. (1969). LANKAWE WYAWAHARA KASI HA MUDAL. Colombo. Sinahla. 